\title{
IN MEMORIAN
}

\section{PROF. KARL KLEIST}

$1879-1960$

A 26 de dezembro de 1960 deixou de existir objetivamente o insigne Prof. Karl Kleist, para quem fôra criado especialmente o Pôsto de Frankfurt am Main para Pesquisa em Patologia Cerebral e em Psicopatologia.

Alsaciano de origem, pois nasceu em Mülhausen a 31-1-1879, concluiu o curso médico em München, onde se diplomou em 1902. Dedicou-se logo, e com afinco, à docência da psiquiatria, que exerceu de 1903 a 1908 (Lehrjahre) em Halle der Saale, em Frankfurt am Main e em München. Tivera assim a formação psiquiátrica presidida principalmente por Wernicke o qual nos últimos anos o tivera como assistente - pois Wernicke faleceu em 1905 - e de quem Kleist sempre se considerou discipulo. Durante o período de rodísio na docência (Wanderjahre), de 1908 a 1909, em München e em Erlangen, e só então como o fêz notar recentemente, conheceu mais de perto a Kraepelin e a Bleuler. São dêsses 2 anos, respectivamente, os volumes sôbre "Alterações psicomotoras da motilidade em doentes mentais" e "Novas pesquisas em doentes mentais com distúrbios psicomotores" com o qual conquistou a venia legendi. Foi médico-chefe da Clínica NeuroPsiquiátrica de Erlangen desde essa época até 1915 quando aí se tornou professor extraordinário de psiquiatria. No ano seguinte, como professor ordinário assumiu a cátedra de Rostock onde se manteve até 1919 quando foi convidado para a de Frankfurt am Main. Aqui permaneceu até o fim da carreira docente, pois recusou o convite para o pôsto máximo da psiquiatria alemã, a cátedra de Berlim. Em Frankfurt am Main organizou em novas bases a Clínica Neuropsiquiátrica, a qual tornou célebre aquela Universidade e o método Kleistiano de investigação da patologia cerebral. $\mathrm{Na}$ solenidade em que se tornou emérito, ao proferir a aula de despedida da cátedra, recebeu a investidura no Pôsto para Pesquisa em Patologia Cerebral e em Psicopatologia, criado conjuntamente pela Municipalidade e pela Universidade. Em reconhecimento pelo incomparável renome cientifico granjeado para a cidade e para a pesquisa, foi agraciado em 1954 com a medalha de Goethe, com o título de doutor honoris causa em medicina, da Universidade de Frankfurt am Main, e com o de cidadão honorário de Frankfurt am Main. Entre as várias sociedades que o elegeram sócio honorário figuram o Centro de Estudos "Franco da Rocha" e o Departamento de Neuro-Psiquatria da Associação Paulista de Medicina.

Kleist inaugurou métodos inteiramente novos no domínio da neuropsiquiatria. Deu à patologia cerebral um sentido essencialmente dinâmico, 
não só aprofundando os vários sindromes no sentido de filiá-los a áreas e a sistemas cerebrais, como distinguindo entre êles os que dependem de desvios globais ligados a regiões do tronco cerebral e os que decorrem de alterações isoladas, no âmbito cortical. Estabeleceu métodos refinados para a investigação neurológica e psiquiátrica, a princípio com pacientes de doenças mentais endógenas e depois com feridos cerebrais da primeira Guerra Mundial. Chegou assim a construir a carta funcional do cérebro baseada nos estudos arquitetônicos - das células e das fibras corticais - carta essa intrìnsecamente dinâmica. No domínio das doenças mentais empreendeu tarefa gigantesca, que se firmou logo aos primeiros anos de docência e que se manteve até os últimos tempos, sempre confirmada e ampliada. Começou ai por destrinçar, à maneira de Wernicke, entidades clínicas diversas que os autores em geral confundiam como constituindo uma mesma unidade mórbida. Assim isolou as psicoses endógenas de decurso benigno, genèticamente aparentadas com as diversas psicoses endógenas clássicas, mas fenomenologicamente confundidas com a demência precoce, e depois com a esquizofrenia. E no campo das demências primárias e progressivas descreveu 26 formas autônomas, com quadro clínico plenamente identificável e de tendência genética definida. Além disso inaugurou a investigação catamnéstíca dos pacientes — após pelo menos cinco anos de evolução mơrbida - como critério sistemático para estabelecer a autonomia ou a inconsistência do quadro clínico originàriamente diagnosticado.

Certamente essa intensidade de esfôrço e êsse incomum espírito inovador que tais pesquisas subentendem fizeram com que as concepções de Kleist não entrassem de imediato nos meios psiquiátricos. Critério rigoroso no raciocínio e responsabilidade implicada pelo diagnóstico, são realmente condições que não condizem com as tendências dominantes neste setor da arte médica. Todavia dezenas de novos pesquisadores - muitos dêles logo reconhecidos como autoridade na psiquiatria — se associaram ao insigne mestre de Frankfurt am Main. Assim, e ao mesmo tempo que o pensamento médico e psiquiátrico amadurecia gradativamente, a doutrina de Kleist foi encontrando acolhida e confirmação sempre crescentes. Hoje ninguém pode haver-se condignamente na arte psiquiátrica ou na doutrina psicopatológica sem considerar as conquistas daquele fundador de escola e de concepção neuropsiquiátrica.

Em São Paulo, como em todo centro da especialidade, as idéias de Kleist orientam de há muito a investigação clínica. Desde 1932 observações clínicas do Hospital de Juquerí e trabalhos apresentados nas reuniōes dos médicos psiquiatras - antecessoras do Centro de Estudos "Franco da Rocha" fundado em 1942 - tomavam por base aquela doutrina. Com o ingresso de psiquiatras jovens para o Corpo Clínico daquele estabelecimento, tal orientação deixou de ser individual e logo deu origem à formação de um grupo definido. Assim naquela tradicional casa de Franco da Rocha foi comemorado o $700^{\circ}$ aniversário de Kleist, em 1949, com uma Sessão Solene em que se discutiram 6 temas teóricos e numerosos casos clínicos, apresentados por 13 psiquiatras, 2 neuro-cirurgiões e um anátomo-patologista. Em 1954 
foi nesta Capital na Associação Paulista de Medicina e em reunião conjunta do Centro de Estudos "Franco da Rocha", do Departamento de NeuroPsiquiatria e da Sociedade Rorschach de São Paulo que se comemorou o $75 .^{\circ}$ natalício. E por ocasião do $80 .^{\circ}$ aniversário aquelas mesmas associações o homenagearam; e, sobretudo, ARquivos dE NEURo-PISIQUiatria publicaram um número especial de homenagem (vol. 17, n. ${ }^{\circ} 2,1959$ ).

Agradecendo a esta publicação em cartas individuais ao editor de ARQUIvos DE Neuro-Pisiquiatria e a cada um dos colaboradores do fascículo, Kleist revelou - pelos comentários muito específicos e até pela corrigenda de alguns lapsos que haviam escapado à revisão - ter lido todos os trabalhos na íntegra. Na data mesmo de 31 de janeiro de 1959 recebera o telegrama congratulatório dos 3 agrupamentos psiquiátricos de São Paulo, com a notícia da homenagem conjunta. Foi a modesta contribuição de psiquiatras de São Paulo para um último preito natalício periódico, que nessa oportunidade se tornou verdadeira apoteóse, pois Kleist assim o descreveu no comedido agradecimento impresso:

"Por meu $80 .^{\circ}$ aniversário fui cumulado de homenagens, de oferendas, de votos de felicidade, como penhor de reconhecimento e de gratidão, de afeto, de amizade e de fidelidade, em frases e em palavras impressas, em telegramas, em cartas e em cartões. De perto e de longe vieram discipulos, colaboradores, amigos, de tempos antigos e recentes. $\mathrm{Na}$ mesa de presentes acumulavam-se livros e outros presentes. Os cômodos de minha casa quase não podiam comportar a messe de flôres. Profundamente tocado, consciente da mercê de uma longa vida, agradeço a todos."

Não foi por certo apenas por efeito da longa vida, mas sim pela profundidade e pela incrivel extensão das reformas empreendidas no pensamento psiquiátrico, que a atividade incomparável de Kleist conquistou o reconhecimento, mesmo em vida, de todos os centros neuropsiquiátricos.

ANIBAL SILVEIRA 